\title{
Hubungan antara Tingkat Pengetahuan dan Sikap dengan Tindakan Pencegahan Penyakit Rabies pada Warga di Wilayah Puskesmas Kuta II
}

\author{
Ni Kadek Ayu Septiani Sarjana ${ }^{1}$, Arsita Eka Prasetyawati ${ }^{2}$, Dyah Ratna Budiani ${ }^{3}$ \\ 1.Program Studi Kedokteran, Fakultas Kedokteran Universitas Sebelas Maret \\ 2.Departemen Ilmu Kesehatan Masyarakat Fakultas Kedokteran Universitas Sebelas Maret \\ 3.Departemen Patologi Anatomi Fakultas Kedokteran Universitas Sebelas Maret
}

Korespondensi : arsita.ep@gmail.com

\begin{abstract}
ABSTRAK
Pendahuluan: Rabies merupakan penyakit pada hewan (biasanya vertebrata) yang dapat ditransmisikan ke manusia (zoonotic). Rabies disebabkan oleh infeksi virus yang merupakan Family: Rhabdivoridae, Genus: Lyssavirus. Vaksinasi pada binatang anjing merupakan metode yang efektif dan ekonomis dalam mencegah transmisi infeksi rabies ke manusia. Penelitian ini bertujuan untuk mengetahui hubungan antara tingkat pengetahuan dan sikap terhadap penyakit rabies terhadap tindakan pencegahan penyakit rabies pada masyarakat di wilayah Puskesmas Kuta II, provinsi Bali, Indonesia.

Metode: Penelitian ini merupakan studi cross sectional dengan mengamati masyarakat. Pengambilan sampel dengan cara simple random sampling dari 96 penduduk di wilayah Puskesmas Kuta II. Variabel bebas adalah pengetahuan dan sikap terhadap penyakit rabies. Variabel terikat adalah tindakan pencegahan penyakit rabies. Data diambil dengan menggunakan questionnaire-based interview. Data dianalisis menggunakan chi-square $\left(x^{2}\right)$ dengan analisis multivariate menggunakan multiple logistic regressions.

Hasil: Penelitian ini menunjukkan hubungan yang signifikan pada tindakan pencegahan penyakit rabies ( $p=0.013$; OR 4.240; $95 \%$ CI 1.352 up to 13.296). Sikap mempunyai hubungan yang positif dengan nilai praktek tindakan pencegahan penyakit rabies $(\mathrm{p}=$ 0.015; OR 3.073; 95\% CI 1.233 up to 7.627). Efek dari tingkat pengetahuan dan sikap secara bersamaan terhadap tindakan untuk pencegahan penyakit rabies adalah sekitar $20.90 \%$ (Negerkerke R square $=0.209$ ).

Kesimpulan: Terdapat hubungan yang signifikan antara tingkat pengetahuan dan sikap terhadap tindakan pencegahan penyakit rabies pada warga di wilayah Puskesmas Kuta II, tindakan pencegahan penyakit rabies pada masyarakat di wilayah Puskesmas Kuta II.
\end{abstract}

Kata Kunci: Rabies; Rabies; Pencegahan; Tingkat-pengetahuan; Sikap

\begin{abstract}
Introduction: Rabies is a disease of animals (usually vertebrate) which is zoonotic (transmissible to humans). Rabies occurs in 24 out of the 34 provinces of Indonesia. Rabies is caused by a virus in the Family: Rhabdivoridae, Genus: Lyssavirus. Control the dog population and dog vaccination is effective and economical method to prevent the incidences of rabies in humans. This study aims to investigate the relationship between level of knowledge and attitude to the practice in prevention rabies infection in residents lived in area covered by Puskesmas Kuta II.

Methods: This study was a cross-sectional study and carried out by simple random sampling of 96 residents in the area of Puskesmas Kuta II. In this study, the independent variables are knowledge of and attitudes towards rabies disease while the dependent variable is the practice to prevent rabies infection in human. Data were collected by a
\end{abstract}


Sarjana, et. al., Hubungan antara tingkat pengetahuan dan sikap dengan tindakan pencegahan penyakit rabies pada warga di wilayah Puskesmas Kuta II

\begin{abstract}
questionnaire-based interview. Analyses were then carried out using the chi-square $\left(x^{2}\right)$ followed by multivariate analysis using multiple logistic regressions.

Results: This study showed that knowledge has a significant relationship with practice for rabies disease prevention ( $p=0.013$; OR 4.240; 95\% CI 1.352 up to 13.296). Attitude has a significant positive relationship with the value of practice for rabies disease prevention ( $p=0.015$; OR 3.073; 95\% CI 1.233 up to 7.627). The combined effect of knowledge and attitudes to practice for rabies prevention were approximately $20.90 \%$ (Negerkerke R square $=0.209$ ).

Conclusions: There was a significant relationship between knowledge and attitudes with the practice for rabies disease prevention in residents in the area of Puskesmas Kuta II, the higher level of knowledge and improved attitudes will improve practice for rabies disease prevention amongst residents in the area of Puskesmas Kuta II.
\end{abstract}

Key words: Rabies; Rabies; Preventio; Knowledge; Attitude; Practice

\section{PENDAHULUAN}

Rabies merupakan salah satu penyakit zoonosis yaitu penyakit yang menular dari hewan ke manusia. Infeksi ini ditularkan oleh hewan yang terinfeksi penyakit rabies. Hewan yang dapat sebagai penyebab penyebaran rabies adalah: anjing, rakun, rubah, monyet dan kelelawar ${ }^{1}$.

Rabies pertama kali dilaporkan di Indonesia pada tahun 1884 dan sekarang kejadian rabies tersebar hamper diseluruh provinsi di Indonesia ${ }^{2}$. Pada tahun 2008, dilpaorkan adanya kematian manusia pertama dari infeksi virus rabies setelah digigit anjing yang terjadi di Ungasan, Bali. Pada tahun 2009, dilaporkan terjadinya 27 kasus pada manusia didaerah Tabanan dan Ungasan, bali. Pada tahun 2010, jumlah kematian manusia dilaporkan telah melampaui 40 orang $^{3}$.

Menurut data yang dikumpulkan oleh sebuah Lembaga Swadaya Masyarakat (LSM), perbandingan populasi manusia dan anjing di Bali diperkirakan 1:6.5 (antara 5-8). Dengan jumlah penduduk Bali sebanyak 3.5 juta jiwa, jumlah populasi anjing diperkirakan sekitar 540000 ekor, atau 96 ekor/ $/ \mathrm{km}^{2}$. Jumlah tersebut termasuk anjing yang dirumahkan (dirantai, dikandangkan atau dilepaskan dalam pagar rumah) anjing dengan pemilik yang dirumahkan dan dilepas, anjing dengan pemilik yang dilepaskan dan anjing tanpa pemilik. Proporsi anjing yang dirumahkan kurang dari $30 \%$, sisanya merupakan anjing liar. Untuk jumlah anjing di wilayah Kuta mencapai 6502 ekor anjingt ${ }^{4}$.

Kondisi ini mengakibatkan warga di wilayah Kuta berisiko tinggi terkena penyakit rabies. Hal ini harus segera ditanggulangi agar tidak menyebabkan bertambahnya korban jiwa akibat rabies dan tidak menimbulkan keresahan dari warga. Diketahui bahwa pengetahuan dan sikap akan mempengaruhi tindakan pencegahan. Tindakan pencegahan terhadap penyakit rabies akan menurunkan jumlah korban jiwa akibat penyakit ini.

Hal tersebut menarik perhatian peneliti untuk meneliti hubungan antara tingkat pengetahuan dan sikap dengan tindakan pencegahan penyakit rabies pada warga di wilayah Puskesmas Kuta II.

\section{METODE}

Penelitian ini merupakan jenis penelitian observasional analitik dengan desain cross sectional. Penelitian ini dilaksanakan pada bulan Agustus-September 2014 di wilayah Puskesmas Kuta II Kabupaten Badung Bali. Populasi yang digunakan dalam penelitian ini adalah seluruh warga yang bertempat tinggal di wilayah Puskesmas Kuta II. Pengambilan sampel dilakukan secara simple random sampling dengan kriteria inklusi warga yang memiliki anjing di wilayah Puskesmas Kuta II serta bersedia ikut penelitian dengan persetujuan 
Sarjana, et. al., Hubungan antara tingkat pengetahuan dan sikap dengan tindakan pencegahan penyakit rabies pada warga di wilayah Puskesmas Kuta II

tulisan dan kriteria eksklusi warga yang memiliki anjing lebih dari 5 di wilayah Puskesmas Kuta II.

Variabel bebas pada penelitian ini adalah tingkat pengetahuan terhadap penyakit rabies dan sikap terhadap penyakit rabies. Tingkat pengetahuan terhadap penyakit rabies adalah apakah responden mengetahui, pernah melihat atau mendengar tentang penyakit rabies. Meliputi pengertian tentang rabies, gejala-gejala atau tanda-tanda manusia maupun hewan yang tertular rabies, faktor penyebab, hewan penular, cara penularan, cara pencegahan penyakit rabies, dan cara pertolongan pertama bila terjadi gigitan. Variabel ini diukur menggunakan kueisioner dengan skala pengukuran kategori dikotomi, tingkat pengetahuan tinggi dan tingkat pengetahuan rendah. Sikap terhadap penyakit rabies adalah adalah tanggapan dari responden yaitu, setuju atau tidak setuju terhadap pernyataan-pernyataan yang berhubungan dengan pencegahan penyakit rabies, diantaranya cara pemeliharaan anjing yang baik, dan pertolongan pertama bila terjadi gigitan hewan penular rabies. Variabel ini diukur menggunakan kueisioner dengan skala pengukuran kategori dikotomi, sikap tinggi dan sikap rendah.

Variabel terikat pada penelitian ini adalah tindakan pencegahan terhadap penyakit rabies. Tindakan pencegahan terhadap penyakit adalah perbuatan nyata yang dilakukan oleh responden terhadap pencegahan penyakit rabies, meliputi cara pemeliharaan anjing yang baik, dan cara pertolongan pertama bila terjadi gigitan oleh hewan penular rabies. Variabel ini diukur menggunakan kueisioner, dengan skala pengukuran katagorik dikotomi, tingkat pengetahuan tinggi dan tingkat pengetahuan rendah.

Data dalam penelitian ini dianalisis dengan metode statistik Uji Chi Square $\left(\mathrm{X}^{2}\right)$. Selanjutnya dilakukan analisis multivariat dengan menggunakan analisis regresi logistik ganda.

\section{HASIL}

Berdasarkan hasil distribusi frekuensi variabel yang diperoleh menggunakan analisis univariat, didapatkan bahwa sebagian besar responden telah mempunyai pengetahuan tinggi yaitu sebanyak 75 responden $(78.10 \%)$ sedangkan pada variabel sikap dan tindakan yang dimiliki responden, antara sikap rendah dan sikap tinggi memiliki selisih yang sedikit demikian pula pada tindakan rendah dan tindakan tinggi memiliki selisih yang sedikit, seperti yang telah tercantum dalam Tabel 1 .

Tabel 1. Distribusi Frekuensi Pengetahuan, Sikap, dan Tindakan terhadap Pencegahan Penyakit Rabies.

\begin{tabular}{lrr}
\hline Variabel & Frekuensi & $\begin{array}{r}\text { Persentase } \\
(\%)\end{array}$ \\
\hline Pengetahuan & & \\
Rendah & 21 & 21.90 \\
Tinggi & 75 & 78.10 \\
Jumlah & 96 & 100.00 \\
\hline Sikap & & \\
Rendah & 56 & 58.30 \\
Tinggi & 40 & 41.70 \\
Jumlah & 96 & 100.00 \\
\hline Tindakan & & \\
Rendah & 44 & 45.80 \\
Tinggi & 52 & 54.20 \\
Jumlah & 96 & 100.00 \\
\hline Sumber: Data primer, 2014 &
\end{tabular}

Berdasarkan analisis bivariat variabel tingkat pengetahuan dengan tindakan pencegahan penyakit rabies, diperoleh hasil seperti Tabel 2 bahwa kelompok pengetahuan rendah mempunyai tindakan rendah sebesar 16 orang $(16.7 \%)$, pengetahuan rendah mempunyai tindakan tinggi sebanyak 5 orang (5.20\%), pengetahuan tinggi tindakan rendah sebanyak 28 orang $(29.20 \%)$ dan pengetahuan tinggi mempunyai tindakan tinggi sebesar 47 orang (49\%). Hubungan antara tingkat 
Sarjana, et. al., Hubungan antara tingkat pengetahuan dan sikap dengan tindakan pencegahan penyakit rabies pada warga di wilayah Puskesmas Kuta II

pengetahuan dengan tindakan pencegahan penyakit rabies bermakna secara statistik $(\mathrm{P}=$ $0.002)$.

Tabel 2. Hubungan Tingkat Pengetahuan dengan Tindakan Pencegahan Penyakit Rabies.

\begin{tabular}{|c|c|c|c|}
\hline \multirow{2}{*}{ Pengetahuan } & \multicolumn{2}{|c|}{ Tindakan } & \multirow[t]{2}{*}{$\mathrm{P}$} \\
\hline & Rendah & Tinggi & \\
\hline Rendah & $16(16.7 \%)$ & $5(5.2 \%)$ & 0.002 \\
\hline Tinggi & $28(29.2 \%)$ & $47(49.0 \%)$ & \\
\hline Jumlah & $44(45.8 \%)$ & $52(54.2 \%)$ & \\
\hline
\end{tabular}

Sumber: Data Primer, 2014

Hasil analisis bivariat variabel sikap dengan tindakan pencegahan penyakit rabies dalam Tabel 3, menunjukkan bahwa kelompok sikap rendah mempunyai tindakan rendah sebesar 33 orang (34.4\%), sikap rendah mempunyai tindakan tinggi sebanyak 23 orang (24.0\%), sikap tinggi tindakan rendah sebanyak 11 orang (11.50\%) dan sikap tinggi mempunyai tindakan tinggi sebesar 29 orang $(30.2 \%)$. Hubungan antara sikap dengan tindakan pencegahan penyakit rabies bermakna secara statistik $(\mathrm{P}=0.002)$.

Tabel 3. Hubungan Sikap dengan Tindakan Pencegahan Penyakit Rabies.

\begin{tabular}{lccc}
\hline Sikap & \multicolumn{2}{c}{ Tindakan } & $\mathrm{P}$ \\
\cline { 2 - 3 } & Rendah & Tinggi & \\
\hline Rendah & $33(34.2 \%)$ & $23(24.0 \%)$ & 0,002 \\
Tinggi & $11(11.5 \%)$ & $29(30.2 \%)$ & \\
Jumlah & $44(45.8 \%)$ & $52(54.2 \%)$ & \\
\hline
\end{tabular}

Sumber: Data Primer, 2014

Berdasarkan hasil analisis mutivariat pada Tabel 4, variabel pengetahuan mempunyai nilai $\mathrm{p}=0.013(\mathrm{p}<0.05)$. Hal ini menunjukkan bahwa pengetahuan mempunyai hubungan bermakna dengan tindakan pencegahan penyakit rabies. Nilai Odds Ratio sebesar 4.24 dengan interval kepercayaan 95\% (CI 95\%) antara 1.352 sampai dengan 13.29 yang berarti pengetahuan memiliki resiko meningkatkan sebesar 4.24 kali terhadap tindakan pencegahan penyakit rabies.

Variabel sikap mempunyai nilai $\mathrm{p}=$ 0.015 ( $p<0.05)$. Hal ini menunjukkan bahwa sikap mempunyai hubungan bermakna dengan tindakan pencegahan penyakit rabies. Nilai Odds Ratio adalah 3.07 dengan interval kepercayaan 95\% (CI 95\%) antara 1.233 sampai dengan 7.627. Sehingga dapat diketahui bahwa sikap memiliki resiko meningkatkan sebesar 3.07 kali terhadap tindakan pencegahan penyakit rabies.

Tabel 4. Analisis Regresi Logistik

\begin{tabular}{lrr}
\hline & \multicolumn{2}{c}{ Variabel } \\
\cline { 2 - 3 } & Pengetahuan & \multicolumn{1}{c}{ Sikap } \\
\hline Wald & 6.14 & 5.86 \\
Odd Ratio & 4.24 & 3.07 \\
P & 0.013 & 0.015 \\
95\% C.I. & & \\
Lower & 1.35 & 1.23 \\
Upper & 13.29 & 7.63 \\
Negelkerkel R Square $=0.209$ & \\
\hline
\end{tabular}

Sumber: Data Primer, 2014

Hasil Uji Negelkerkel $R$ Square sebesar 0.209 yang berarti pengaruh pengetahuan dan sikap terhadap tindakan pencegahan penyakit rabies sebesar $20.90 \%$, sedangkan sisanya sebesar $79.10 \%$ dipengaruhi oleh variabel lain.

\section{PEMBAHASAN}

Penelitian tentang hubungan antara pengetahuan dan sikap dengan tindakan pencegahan penyakit rabies pada warga dilaksanakan di wilayah Puskesmas Kuta II pada September 2014. Penelitian ini merupakan jenis penelitian observational analitik dengan pendekatan cross sectional. Besar sampel diperoleh 96 sampel dimana pengambilan sampel dilakukan secara simple random sampling.

Uji statistik bivariat bertujuan untuk mengukur dua variabel, pada penelitian ini berfungsi untuk mengetahui hubungan pengetahuan dengan tindakan pencegahan penyakit rabies dan untuk mengetahui hubungan sikap dengan tindakan pencegahan penyakit rabies. Pada penelitian ini hubungan antara pengetahuan dan tindakan pencegahan 
Sarjana, et. al., Hubungan antara tingkat pengetahuan dan sikap dengan tindakan pencegahan penyakit rabies pada warga di wilayah Puskesmas Kuta II

penyakit rabies bermakna secara statistik ( $\mathrm{p}=$ 0.002). Selain itu hubungan antara sikap dengan tindakan pencegahan penyakitt rabies juga bermakna secara statistik ( $\mathrm{p}=0.002)$.

Uji statistik multivariat digunakan untuk menganalisis variabel bebas dan variabel terikat secara bersama. Pada penelitian ini variabel bebas adalah pengetahuan dan sikap, sedangkan variabel terikat adalah tindakan pencegahan terhadap penyakit rabies. Hasil analisis menunjukkan bahwa pengetahuan mempunyai hubungan bermakna terhadap tindakan pencegahan penyakit rabies di wilayah Puskesmas Kuta II ( $\mathrm{p}=0.013$ ) dan Odds Ratio sebesar 4.24 yang artinya pengetahuan meningkatkan tindakan pencegahan penyakit rabies sebesar 4.24 kali. Seseorang memiliki dasar untuk mengambil suatu keputusan dan menentukan tindakan terhadap masalah yang sedang dihadapi bila orang tersebut memiliki pengetahuan ${ }^{5}$.

Secara statistik, beberapa penelitian dengan topik yang berbeda menunjukkan adanya hubungan yang bermakna antara pengetahuan dengan tindakan pencegahan. Seperti hasil yang didapatkan Rahmaditia $^{6}$, pada penelitian dengan judul Hubungan Pengetahuan dan Sikap Ibu Terhadap Tindakan Pencegahan Demam Berdarah Dengue pada Anak di Wilayah Kerja Puskesmas Tlogosari Wetan Kota Semarang, dimana $\mathrm{p}=0.046(\mathrm{p}<0.05)$ berarti secara statistik pengetahuan ibutentang DBD berhubungan dengan tindakan pencegahan penyakit DBD.

Penelitian ini juga senada dengan penelitian sebelumnya oleh Prisaria ${ }^{7}$ dengan judul Hubungan Pengetahuan dan Lingkungan Sosial Terhadap Tindakan Pencegahan Penyalahgunaan NAPZA pada Siswa SMA Negeri 1 Jepara. Hasil uji tersebut menunjukkan bahwa ada hubungan bermakna antara pengetahuan siswa SMA tentang NAPZA terhadap tindakan pencegahan penyalahgunaan NAPZA $(\mathrm{p}=0.0001 ; \mathrm{r}=$ 0.378). Hasil ini menunjukkan bahwa semakin tinggi pengetahuan siswa maka semakin tinggi pula pencegahan terhadap penyalahgunaan NAPZA.

Hasil penelitian ini juga sejalan dengan penelitian Lusi $^{8}$ tentang Hubungan antara Tingkat Pengetahuan dan Sikap Masyarakat tentang Penyakit Filariasis dengan Tindakan Masyarakat dalam Pencegahan Filariasis. Hasil uji statistik menunjukkan bahwa terdapat hubungan yang bermakna antara tingkat pengetahuan masyarakat tentang penyakit filariasis dengan tindakan masyarakat dalam pencegahan filariasis ( $p$ value $=0.035$ ) .

Penelitian dengan hasil yang sama juga diperoleh Rahmayani ${ }^{9}$ tentang Hubungan Pengetahuan dan Sikap dengan Tindakan Pencegahan Penularan HIV-AIDS pada Waria di Kota Padang Tahun 2013. Berdasarkan hasil pengujian ditemukan bahwa terdapat hubungan yang bermakna antara tingkat pengetahuan dengan tindakan pencegahan penularan HIV-AIDS di kota Padang ( $\mathrm{p}=$ 0.040).

Hasil penelitian ini juga senada dengan hasil penelitian terbaru yang dilakukan Rajaratenam ${ }^{10}$ dengan judul Hubungan Tingkat Pengetahuan dan Sikap dengan Tindakan Pencegahan Osteoporosis pada Wanita Usila di Kelurahan Jati dimana hasil analisis secara statistik menunjukkan bahwa terdapat hubungan yang bermakna antara tingkat pengetahuan osteoporosis dengan tindakan pencegahan osteoporosis yang dilakukan di Kelurahan Jati $\mathrm{p}=0.004$ ( $\mathrm{p}$ $<0.05$ ).

Hal ini juga diperkuat dengan hasil peneltian Hampson et al $^{11}$ dengan judul Pajanan Rabies, Profilaksis Pasca Pajanan dan Kematian di Daerah Endemik Rabies Anjing, bahwa kurangnya pengetahuan tentang bahaya penyakit rabies berikut pencegahannya, khususnya tindakan profilaksis pasca pajanan dan manajemen luka, adalah penyebab utama kematian rabies. Edukasi, khususnya di masyarakat miskin dan terpinggirkan dan juga 
Sarjana, et. al., Hubungan antara tingkat pengetahuan dan sikap dengan tindakan pencegahan penyakit rabies pada warga di wilayah Puskesmas Kuta II

tenaga medis dan dokter hewan, akan mencegah kematian akibat rabies di masa depan.

Hasil analisis data menunjukkan bahwa sikap mempunyai hubungan terhadap tindakan pencegahan penyakit rabies, hal ini dapat dilihat dari uji statistik bahwa nilai $\mathrm{p}=$ 0.015 ( $\mathrm{p}<0.05$ ), dan Odds Ratio sebesar 3.07 yang artinya sikap meningkatkan tindakan pencegahan penyakit rabies sebesar 3.07 kali. Sikap merupakan komponen yang mendahului tindakan atau perilaku terbuka, sikap adalah ancang-ancang untuk bertindak atau berperilaku terbuka (tindakan).

Beberapa penelitian lain yang berbeda topik, secara statistik juga menunjukkan bahwa terdapat hubungan bermakna antara sikap dengan tindakan pencegahan. Pernyataan ini didukung dengan hasil penelitian yang dilakukan oleh Pinandita ${ }^{12}$ dengan judul Hubungan Antara Pengetahuan dengan Sikap Lansia Penderita Osteoporosis Dalam Upaya Pencegahan Jatuh di Rumah di Puskesmas Kartasura bahwa terdapat hubungan yang bermakna antara sikap dengan tindakan pencegahan osteoporosis dengan nilai $\mathrm{p}=0.014(\mathrm{p}<0.05)$.

Hasil yang sepaham juga didapatkan oleh Rahim ${ }^{13}$ dengan judul Hubungan Pengetahuan dan Sikap Ibu Balita dengan Perilaku Pencegahan Penyakit Pneumonia di Wilayah Kerja Puskesmas Putri Ayu tahun 2013 didapatkan hasil analisis statistik menggunakan chi-square menunjukkan $\mathrm{p}$ value sebesar 0.000 , dimana $p<0.05$ yang berarti ada hubungan antara sikap ibu balita tentang pencegahan penyakit pneumonia dalam perilaku pencegahan penyakit pneumonia di wilayah kerja Puskesmas Putri Ayu Kota Jambi Tahun 2013.

Hasil yang tak berbeda juga didapatkan oleh Rahmayani $^{7}$ dalam peneltiannya Hubungan Pengetahuan dan Sikap dengan Tindakan Pencegahan Penularan HIV-AIDS pada Waria di Kota Padang Tahun 2013, dimana hasil analisis hubungan antara sikap dengan tindakan pencegahan penularan penyakit HIV-AIDS, didapatkan hubungan yang bermakna antara keduanya ( $\mathrm{p}<0.05$ yaitu 0.048 ).

Hasil yang serupa juga didapatkan dalam penelitian terbaru oleh Rajaratenam ${ }^{10}$ dengan judul Hubungan Tingkat Pengetahuan dan Sikap dengan Tindakan Pencegahan Osteoporosis pada Wanita Usila di Kelurahan Jati, dimana hasil analisis menunjukkan terdapatnya hubungan yang bermakna antara sikap dengan tindakan pencegahan osteoporosis dengan nilai $\mathrm{p}=0.001(\mathrm{p}<0.05)$. Hasil ini didukung dengan penelitian sebelumnya oleh Ali et al ${ }^{14}$ dengan judul Studi Pengetahuan, Sikap dan Tindakan Penyakit Rabies di Antara Penduduk di Addis Ababa, Ethiopia dimana hasil analisis korelasi menunjukkan bahwa terdapat korelasi positif yang kuat; antara Pengetahuan dan Sikap, antara Pengetahuan dan Tindakan, serta Sikap dan Tindakan Penyakit Rabies.

Pada hasil penelitian terdapat ini hubungan antara tingkat pengetahuan dan sikap dengan tindakan pencegahan penyakit rabies pada warga di wilayah Puskesmas Kuta II, karena tindakan ini didasarkan atas pengetahuan dan sikap masyarakat terhadap penyakit rabies itu sendiri.

Menurut penelitian oleh Matibag et al ${ }^{15}$ tentang Survei Pengetahuan, Sikap, dan Tindakan Rabies dalam komunitas di Sri Lanka, disimpulkan bahwa kemudahan akses terhadap fasilitas dan layanan dapat tercemin dalam sikap dan tindakan responden yang akan memungkinkan partisipasi masyarakat dalam pengendalian rabies. Misalnya seseorang yang sudah tahu penyakit rabies itu berbahaya, maka dia memiliki niat (sikap) untuk menjaga kesehatan anjingnya.

Menurut Wattimena dan Suharyo ${ }^{16}$ sikap terhadap pencegahan penyakit rabies salah satunya adalah sikap terhadap cara pemeliharaan anjing yang baik. Beberapa hal penting yang harus diperhatikan dalam memelihara anjing yang baik diantaranya 
Sarjana, et. al., Hubungan antara tingkat pengetahuan dan sikap dengan tindakan pencegahan penyakit rabies pada warga di wilayah Puskesmas Kuta II

memberi makanan anjing 2-4 kali sehari, memandikan anjing lebih dari sekali dalam seminggu, memotong kuku anjing secara teratur karena kuku dapat menjadi sarang virus rabies, tidak memotong anjing untuk dijadikan makanan, anjing dikurung di dalam rumah atau di halaman rumah yang berpagar, memberi vaksinasi rabies pada anjing secara teratur, menghindarkan anjing berkelahi dengan hewan lainnya, dan menggunakan rantai saat mengajak anjing jalan-jalan. Bila masyarakat memiliki sikap yang baik terhadap cara pemeliharaan anjing maka hal ini sangatlah membantu dalam mencegah terjadinya penyakit rabies.

\section{KESIMPULAN}

Terdapat hubungan bermakna antara pengetahuan dengan tindakan pencegahan penyakit rabies. Dimana pengetahua meningkatkan tindakan pencegahan penyakit rabies sebesar 4.24 kali.

Terdapat hubungan bermakna antara sikap dengan tindakan pencegahan penyakit rabies. Dimana sikap meningkatkan tindakan pencegahan penyakit rabies sebesar 3.07 kali.

\section{UCAPAN TERIMA KASIH}

Penulis mengucapkan terimakasih kepada Ari N. Probandari, dr., MPH, Ph. D dan Sarsono, Drs. M.Si yang telah memberikan bimbingan, kritik, dan saran yang sangat membantu selama penelitian hingga penulisan naskah publikasi.

\section{DAFTAR PUSTAKA}

1. Yousaf MZ, Qasim M, Zia S, Khan R, Ashfaq U,Khan S (2012). Rabies Molecular Virology, Diagnosis, Prevention, and Treatment. Virology Journal 9:50

2. 2. Putra AAG, Hampsoon K, Girardi J, Hilby E, Knobel DJ, Mardiana W, Townsend S et al., (2013). Response to a Rabies Epidemic, Bali, Indonesia, 2008-

\section{Emerging Infectious Disease., 19(4): 648-651}

3. Gautret P, Lim PL, Shaw M, Leder K, (2010). Rabies post-exposure prophylaxis in travellers returning from Bali, Indonesia, November 2008 to March 2010. Clinical and Microbiology Infection, 17(3): 445-447

4. Besung K, Suwiti NK, Suatha IK, Suastika P, Piraksa IW, Eka Setiasih NL (2011). Vaksinasi, Edukasi dan Eliminasi Anjing Liar Sebagai Usaha Percepatan Penanggulangan Penyakit Rabies di Bali. Udayana Mengabdi 10 (2): 57 - 60

5. Mubarak (2007). Promosi Kesehatan. Yogyakarta: Graha Ilmu

6. Rahmaditia T (2011). Hubungan Pengetahuan dan Sikap Ibu Terhadap Tindakan Pencegahan Demam Berdarah Dengue Pada Anak (Di Wilayah Kerja Puskesmas Tlogosari Wetan Kota Semarang). Semarang, Indonesia, Universitas Diponogoro. Disertasi.

7. Prisaria N (2012). Hubungan antara Tingkat Pengetahuan Siswa SMA, Lingkungan Sosial dengan Tindakan Siswa SMA Negeri 1 Jepara dalam Pencegahan Penyalahgunaan NAPZA. Semarang, Indonesia, Universitas Diponegoro. Disertasi.

8. Lusi I (2013). Hubungan antara Tingkat Pengetahuan dan Sikap Masyarakat tentang Penyakit Filariasis dengan Tindakan Masyarakat dalam Pencegahan Filariasis. Riau, Indonesia, Universitas Riau. [Disertasi].

9. Rahmayani V, Hanif AM, Sastri S (2014). Hubungan pengetahuan dan sikap dengan tindakan pencegahan penularan HIVAIDS pada waria di Kota Padang tahun 2013. Jurnal Kesehatan Andalas., 3(2)

10. Rajaratenam S, Martini R, Lipoeto N (2014). Hubungan tingkat pengetahuan dan sikap dengan tindakan pencegahan osteoporosis pada wanita usila di Kelurahan Jati. Jurnal Kesehatan Andalas., 3(2)

11. Hampson K, Dobson A, Kaare M, Dushoff J, Magoto M, Sindoya E, Cleaveland S (2008). Rabies Exposures, 
Sarjana, et. al., Hubungan antara tingkat pengetahuan dan sikap dengan tindakan pencegahan penyakit rabies pada warga di wilayah Puskesmas Kuta II

Post-Exposure Prophylaxis and Deaths in a Region of Endemic Canine Rabies. PLoS Neglected Tropical Disease. 2(11): e399

12. Pinandita N (2011). Hubungan antara Pengetahuan dan Sikap Lansia Penderita Osteoporosis dalam Upaya Pencegahan Jatuh di Rumah di Puskesmas Kartasura. Surakarta, Indonesia, Universitas Muhammadiyah Surakarta. Disertasi.

13. Rahim R (2013). Hubungan Pengetahuan dan Sikap Ibu Balita dengan Perilaku Pencegahan Penyakit Pneumonia di Wilayah Kerja Puskesmas Putri Ayu tahun 2013. Jambi, Indonesia, Universitas Jambi. Disertasi.

14. Ali A, Ahmed EY, Sifer D (2013). A Study on Knowledge, Attitude and Practice of rabies among residents in Addis Ababa, Ethiopia. Ethiopia Veterinary Journal. 17(2):19-35

15. Matibag GC, Kamigaki T, Kumarasiri PVR, Wijewardana TG, Kalupahana AW, Dissanayake DRA, De Silva DDN (2007). Knowledge, attitudes, and practices survey of rabies in a community in Sri Lanka. Environmental Health and Preventive Medicine. 12 (2): 84-89

16. attimena JC, Suharyo (2010). Beberapa Faktor Risiko Kejadian Rabies Pada Anjing Di Ambon. KEMAS 6(1): 24-29 